\title{
Communication
}

[Comunicação]

\section{Development of tetra-primer ARMS-PCR protocol to genotype the prolactin receptor SNP 39136666 and assessment of this SNP in Brazilian locally adapted cattle breeds}

\author{
[Desenvolvimento de protocolo de tetra-primer ARMS- PCR para genotipagem do SNP 39136666 \\ do receptor da prolactina e avaliação desse SNP em raças bovinas brasileiras \\ localmente adaptadas]
}

\author{
D.R.L.R. Faza ${ }^{1}$, H.P. Pereira ${ }^{2}$, A.A. Egito ${ }^{3}$, R.A.A. Torres Júnior ${ }^{3}$, E.S. Kim ${ }^{4}$, \\ T.S. Sonstegard ${ }^{4}$, M.F. Martins ${ }^{1}$, J.C.C. Panetto ${ }^{1}$, \\ M.V.G.B. Silva ${ }^{1}$, M.A. Machado ${ }^{1 *}$ \\ ${ }^{1}$ Centro de Pesquisa de Pecuária de Leite da Embrapa - Juiz de Fora, MG \\ ${ }^{2}$ Universidade Federal de Juiz de Fora - Juiz de Fora, MG \\ ${ }^{3}$ Centro de Pesquisa de Pecuária da Embrapa - Campo Grande, MS \\ ${ }^{4}$ Recombinetics - Saint Paul, United States
}

Cattle herds are highly influenced by environmental conditions and production and reproduction losses caused by high temperatures and humidity have been reported (LandaetaHernandez et al., 2011, Osei-Amponsah et al., 2019). Cattle breeds originated from India (Bos primigenius indicus) are less productive when compared to European breeds under favorable conditions. However, indicine breeds are more resilient and remain productive under unfavorable conditions such as parasitosis, disease and heat stress (Guis et al., 2012; Lemos et al., 2018). Most taurine breeds are adapted to temperate weather and commonly have long, thick and curly hair, subcutaneous fat layers and elongated digestive tract in which rumination generates heat (Martinez et al., 2012; Anderson et al., 2015).

In contrast, indicine breeds have short hair, large skin folds, increased heat flow from the body to the skin and reduced metabolic rate (Turner \& Schleger, 1960). Nevertheless, a small number of taurine breeds (e.g. Senepol) present high heat tolerance due to their short, straight, smooth and lower follicle density hair which is called "slick hair" phenotype (Olson et al., 2003). Taurine animals showing this phenotype are able to control the body temperature under conditions of

Recebido em 1 de julho de 2020

Aceito em 13 de janeiro de 2021

*Autor para correspondência (corresponding author)

E-mail: marco.machado@embrapa.br thermal stress and therefore were able to maintain normal productivity.

Olson et al. (2003) identified a genomic region of dominant inheritance that was able to provide thermal tolerance in Senepol and Carora breeds and their crosses. From these findings, scientific investigations were initiated to unravel the molecular mechanisms involved in this trait. Through the use of microsatellite markers, the slick hair locus was located on bovine chromosome 20, positionally located between markers DIK4835 and DIK2930 (Mariasegaram et al., 2007). Additional genomic wide association study (GWAS) identified two sequence polymorphisms at this locus in Senepol breed and their crosses. One mutation was located in the prolactin gene $(P R L)$ and the other one in its receptor $(P R L R)$ and both showed impact on thermoregulation and hair morphology (Huson et al., 2014; Littlejohn et al., 2014).

The mutation located in the PRPL gene (p.Leu462 *) is a deletion that introduces a premature stop codon in the RNA sequence, resulting in the loss of 120 C-terminal amino acids from the long isoform receptor (ss1067289408; chr20: 39136558GC> G). Porto-Neto et al. (2018) found that p.Leu462* mutation, described by Littlejohn 
et al. (2014), did not explain all slick hair phenotypes found in creole races in Latin America. Analyzing Limonero genome sequences, these authors identified new mutations in PRLR exon 11 which also encode smaller prolactin receptor isoforms. The newly described mutations were P.S465* found in the Limonero breed, and p.R497* found in the Limonero and Carora breeds, but not found in Senepol. These two new mutations combined explain almost $90 \%$ of the slick hair phenotypes in animals that do not carry the mutation found in Senepol. The mutation p.R497 * is caused by a single nucleotide polymorphism (SNP), in which the nucleotide C is replaced by $\mathrm{T}$ at position 39136666 in the prolactin gene (PRLR) of bovine chromosome 20, generating a stop codon in the RNA sequence (Porto-Neto et al., 2018).

SNPs are the current most abundant and used molecular markers in plants and animals although genotyping large numbers of animals by methods involving genotyping by sequencing (GBS) or SNPs microarrays chips remains expensive in developing countries (Ahlawat et al., 2014). Alternatively, the tetra-primer ARMS-PCR is a simple and cost-effective SNP genotyping methodology which involves a single multiplex PCR using outer and inner sets of primers. The outer primers amplify a larger fragment of the target gene, regardless of their SNP genotype, and each inner primer combines with one of the outer primers to generate allele-specific fragments that can be easily visualized through gel electrophoresis, differentiating homozygotes and heterozygotes (Li et al., 2014).

The objective of this work was to develop a simple and low-cost genotyping method for genotyping the SNP 39136666 located in the PRLR gene, which is associated to the slick hair phenotype, using the tetra-primer ARMS-PCR technique and to verify the allelic and genotypic frequencies of this SNP in four locally adapted Iberian derived Brazilian cattle breeds. DNA samples were extracted using biological samples from commercial herds provided by cattle producers of Caracu (beef), Caracu Caldeano (dairy), Crioulo Lageano, Mocho Nacional and Pantaneiro. We used Next Generation Sequencing (NGS) Illumina HiSeq 2500 v4 to sequence the genome of 10 animals of the Caracu breed, which is a locally adapted double purpose
Brazilian breed. Genotypes of SNP 39136666 were obtained from the sequences generated for each sample and used as control to validate the results of the tetra-primer ARMS-PCR procedure. The genotypes found in these sequenced samples were: CC $(n=1), C T(n=3)$ and TT $(n=6)$.

Genome sequences adjacent to SNP 39136666 were used to explore the primer sequences required by the tetra-primer ARMS-PCR technique by means of the Web Tool Primer 1 (Collins \& Ke, 2012). The following primers set was selected: forward inner primer (C allele) 5'AAGCCTGACCAAGACACGGTGTGGCAAC3', reverse inner primer ( $\mathrm{T}$ allele) 5'AGATCAAGGGGGTTTTGTCTTGGGGGCA3', forward outer primer 5' ACCACAGCCACTTCGCTGGACCAAACAG3' and reverse outer primer 5'CAGGATGTTGCTATCTGTCACCCGGGA-3'.

In order to establish the most efficient PCR condition, different concentrations of primer, $\mathrm{MgCl}_{2}$, primer annealing temperatures and the use of the touch down PCR cycling profile were tested. DNA amplification products were detected using $\quad 8 \%$ native, $0.8 \mathrm{~mm}$ thick, 19:1 polyacrylamide gel electrophoresis followed by silver nitrate staining. After the establishment of the tetra-primer ARMS-PCR genotyping protocol, a total of 366 animals from locally adapted Brazilian cattle breeds were selected: 239 Caracu (beef), 61 Caracu Caldeano (dairy), 19 Crioulo Lageano, 14 Mocho Nacional and 33 Pantaneiro animals.

The optimized PCR conditions were performed in $25 \mu \mathrm{L}$ reaction volume containing $50 \mathrm{ng}$ template DNA, 15 pmol of each inner primer and 2.5 pmol of each outer primer, $200 \mu \mathrm{M}$ dNTP, $2 \mathrm{mM}$ $\mathrm{MgCl} 2$, 1X PCR buffer (Promega, Madison, USA) and 0.5U of GoTaq ${ }^{\circledR}$ Hot Start Polymerase (Promega, Madison, USA). Cycling procedure were set as following: $94^{\circ} \mathrm{C}$ for $2 \mathrm{~min}$; followed by five cycles of $30 \mathrm{~s}$ denaturation step $\left(94^{\circ} \mathrm{C}\right), 30$ s annealing step (starting cycle 1 with $70{ }^{\circ} \mathrm{C}$ and decreasing $1^{\circ} \mathrm{C}$ in each cycle) and $30 \mathrm{~s}$ extension step $\left(72^{\circ} \mathrm{C}\right)$; followed by 25 additional cycles of $30 \mathrm{~s}$ denaturation $\left(94^{\circ} \mathrm{C}\right), 30 \mathrm{~s}$ annealing $\left(65^{\circ} \mathrm{C}\right)$ and $30 \mathrm{~s}$ extension $\left(72^{\circ} \mathrm{C}\right)$; and $5 \mathrm{~min}$ at $72^{\circ} \mathrm{C}$ for the final extension step. Figure 1 demonstrates the profile of the DNA amplicons in the gel, clearly differentiating CC, TT and CT genotypes. 


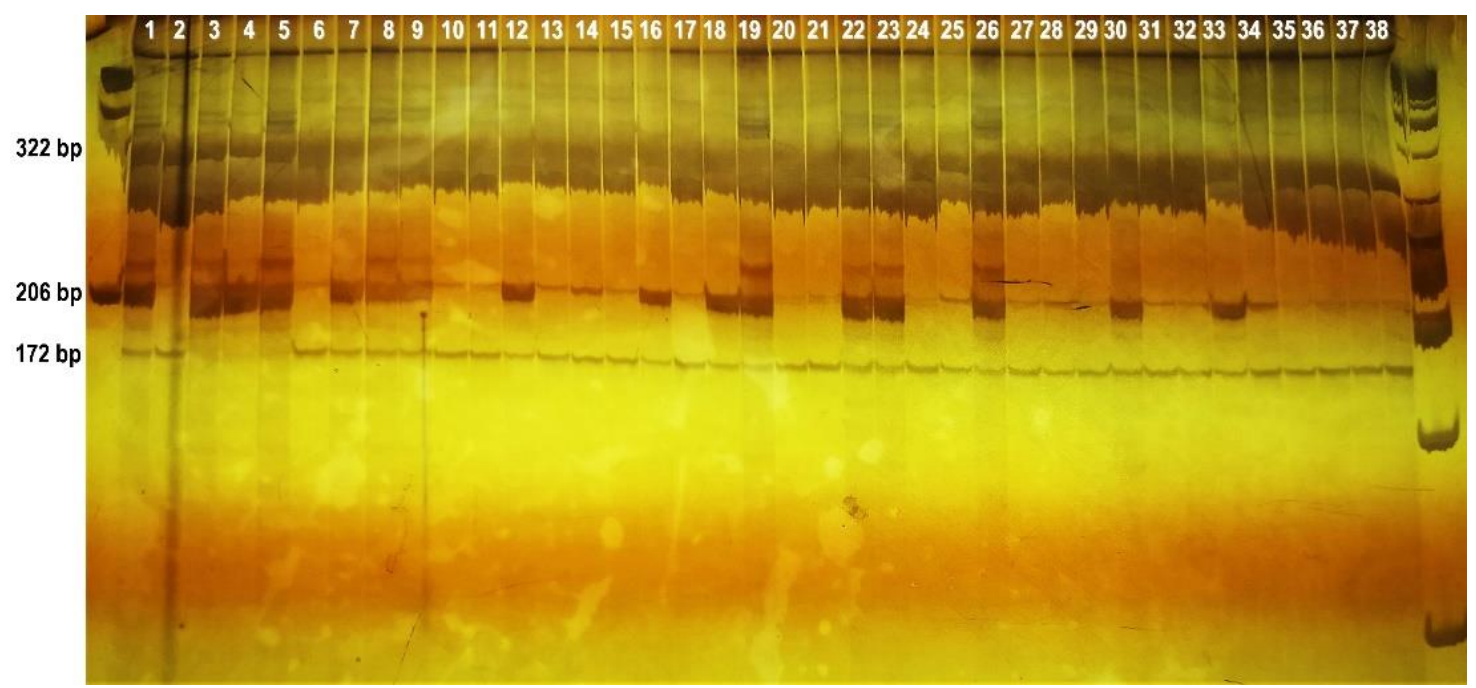

Figure 1. DNA banding pattern from locally adapted Brazilian taurine cattle breeds for the genotyping of the bovine prolactin receptor gene (PRLR) SNP 39136666 using tetra-primer ARMS-PCR technique. Example of an image captured from silver stained $8 \%$ native polyacrylamide gel showing Caracu samples. The $206 \mathrm{bp}$ band indicates the $\mathrm{C}$ allele and the $172 \mathrm{bp}$ band indicates the $\mathrm{T}$ allele. The $322 \mathrm{bp}$ band indicates the product of the outer primers and was used as positive control for the PCR reactions. Genotype CC (lanes $3,4,5$ ), genotype CT (lanes 1, 7, 8, 9, 12, 16, 18, 19, 22, 23, 26, 30, 33) and genotype TT (lanes 2, 6, 10, $11,13,14,15,17,20,21,24,25,27,28,29,31,32,34,35,36,37,38)$.

The tetra-primer ARMS PCR technique was efficient for the precise differentiation between the SNP39136666 alleles of the PRLR gene located at bovine chromosome 20 . The 322 basepair (bp) DNA amplicon was the product of the outer primers which was used as control of the PCR reaction. The length of the amplified DNA amplicons was different enough to be effectively separated in $8 \%$ polyacrylamide gel electrophoresis. The 206 bp DNA amplicon was visualized when the $\mathrm{C}$ allele was present and the 172 bp DNA amplicon when the $\mathrm{T}$ allele was present (Figure 1). The optimal PCR condition was obtained with $6: 1$ concentration ratio between the inner and outer primers and the use of touch down cycling profile. The 10 animals previously sequenced by NGS had their genotypes 100\% confirmed by the protocol developed in this study. The tetra-primer ARMS-PCR genotyping technique was also successfully used to genotype lethal haplotype 1 in Holstein Friesian cattle (Kumar et al., 2020) and AGPAT6 gene, associated with milk fat content in Karan Fries Breeding Bulls (Upadhyay et al., 2019).

Over the past 500 years, periodic introductions of taurine cattle of Iberian origin have occurred in Brazil, resulting in a wide range genetic diversity found today in the locally adapted Brazilian breeds. The p.R497 * mutation, initially described in the Carora and Limoneiro breeds, was also found in the samples assessed in this study. Allelic and genotypic frequencies were calculated for each breed (Table 1). Caracu animals showed the highest frequency of the T allele (75\% and 80\%). In the Mocho Nacional and Pantaneiro breeds, the $\mathrm{C}$ and $\mathrm{T}$ alleles were found averagely distributed within the samples (T 57\% and C 43\%, T $41 \%$ and C 59\%), respectively. Crioulo Lageano breed showed the lowest frequency of the $\mathrm{T}$ allele $(16 \%)$.

As the $\mathrm{T}$ allele is strongly related to the slick hair phenotype, which provides a higher thermal tolerance in cattle, this allele could have been naturally selected over the past 500 years, since this breed is more commonly found in the warmer regions of central Brazil (The Cerrados). On the other hand, Crioulo Lageano breed is more commonly found in the temperate environment of southern Brazil, which would indicate the absence of selective pressure for the $\mathrm{T}$ allele. Since this SNP was recently described by Porto-Neto et al. (2018), we did not find information in the literature regarding the frequency of this SNP in additional cattle breeds. 
Table 1. Observed allelic and genotypic frequencies of SNP 39136666 located at the prolactin receptor gene in locally adapted Iberian derived Brazilian cattle breeds

\begin{tabular}{lcccccc}
\hline \multirow{2}{*}{ Locally adapted cattle breeds } & Number of & \multicolumn{2}{c}{ Allele frequency (\%) } & \multicolumn{2}{c}{ Genotypic frequency (\%) } \\
\cline { 2 - 7 } & animals & T & C & TT & CT & CC \\
\hline Caracu Caldeano (dairy) & 61 & 80 & 20 & 64 & 32 & 4 \\
Caracu (beef) & 239 & 75 & 25 & 54 & 42 & 4 \\
Crioulo Lageano & 19 & 16 & 84 & 0 & 32 & 68 \\
Mocho Nacional & 14 & 57 & 43 & 21 & 71 & 7 \\
Pantaneiro & 33 & 41 & 59 & 18 & 45 & 36 \\
\hline
\end{tabular}

In conclusion, we developed a tetra-primer ARMS-PCR protocol for the identification of the SNP39136666, located at the prolactin receptor gene sequence in cattle, which proved to be a fast, efficient, accurate, and inexpensive alternative for the identification of this SNP. Locally adapted Iberian derived Brazilian Caracu, Crioulo Lagiano, Mocho Nacional and Pantaneiro breeds showed different frequencies of this SNP. Caracu breed showed the highest frequency of the T allele which is directly associated with the slick hair phenotype.

Keywords: short and smooth hair gene, characteristics of tropical adaptation, cattle

\section{RESUMO}

As raças taurinas de origem ibérica Limonero e Carora (Bos primigenius taurus) possuem o fenótipo de pelo curto, liso e com baixa densidade folicular, o que confere a esses animais maior tolerância térmica e melhor produtividade em regiões quentes. Diferentes mutações associadas a esse fenótipo foram descritas no gene do receptor de prolactina PRLR, localizado no cromossomo bovino BTA20. Uma mutação recentemente encontrada é a substituição do nucleotídeo C por T, SNP 39136666 (p. R497*), no exon 11, que gera um códon de parada e, consequentemente, uma menor isoforma desse receptor. Neste trabalho, desenvolveu-se um protocolo rápido e de baixo custo para detecção desse SNP, utilizando-se a técnica de tetra-primer ARMS-PCR. Assim, foi possível detectar essa mutação nas raças brasileiras de origem ibérica localmente adaptadas: Caracu, Crioulo Lageano, Mocho Nacional e Pantaneiro. $O$ alelo $T$ foi mais frequente na raça Caracu (80\%), enquanto o alelo C foi mais frequente na raça Crioulo Lageano (84\%). Essa simples metodologia pode ser usada para genotipar esse SNP e ajudar na aplicação dessas informações moleculares em programas de melhoramento focados na tolerância térmica em bovinos taurinos e seus mestiços.

Palavras-chave: gene do pelo curto e liso, características de adaptação tropical, bovinos

\section{REFERENCES}

AHLAWAT S.; SHARMA R.; MAITRA A. et al. Designing, optimization and validation of tetraprimer ARMS PCR protocol for genotyping mutations in caprine Fec genes. Meta Gene, v.2, p.439-449, 2014.

ANDERSON D.M.; ESTELL, R.E.; GONZALEZ, A.L. et al. Criollo cattle: heritage genetics for arid landscapes. Rangelands, v.3, p.762-767, 2015.

COLLINS, A.W.; KE, X. Primer1: primer design Web service for Tetra-Primer ARMS-PCR. Open Bioinformatics J., v.6, p.55-58, 2012.
GUIS, H.; CAMINADE, C.; CALVETE, C. et al. Modelling the effects of past and future climate on the risk of bluetongue emergence in Europe. $J$. $R$. Soc. Interface, v.9, p.339-350, 2012.

HUSON, H.J.; KIM, E.S.; GODFREY, R.W. et al. Genome-wide association study and ancestral origins of the slick-hair coat in tropically adapted cattle. Front.Genet., v.5, p.1-12, 2014.

KUMAR A.; GUPTA I.D.; MOHAN G. et al. Development of PCR based assays for detection of lethal Holstein haplotype 1, 3 and 4 in Holstein Friesian cattle. Mol. Cell. Probes, v.50, p.101503, 2020. 
LANDAETA-HERNÁNDEZ A.; ZAMBRANONAVA S.; HERNÁNDEZ-FONSECA J.P. et al. Variability of hair coat and skin traits as related to adaptation in Criollo Limonero cattle. Trop. Anim. Health Prod., v.43, p.657-663, 2011.

LEMOS M.V.A.; BERTON M.P.; CAMARGO G.M.F. et al. Copy number variation regions in Nellore cattle: evidences of environment adaptation. Livest. Sci., v.207, p.51-58, 2018.

LI M.; SUN X.; JIANG J. et al. Tetra-primer ARMS-PCR is an efficient SNP genotyping method: An example from SIRT2. Anal. Methods, v.6, p.1835-1840, 2014.

LITTLEJOHN, M.D.; HENTY, K.M.; TIPLADY, K. et al. Functionally reciprocal mutations of the prolactin signalling pathway define hairy and slick cattle. Nat. Commun., v.5, p.1-8, 2014.

MARIASEGARAM M.; CHASE JR. C.C.; CHAPARRO J.X. et al. The slick hair coat locus maps to chromosome 20 in Senepol-derived cattle. Anim. Genet., v.8, p.54-59, 2007.

MARTÍNEZ, A.M.; GAMA, L.T.; CAÑ́N, J. et al. Genetic footprints of Iberian cattle in America 500 years after the arrival of Columbus. PLoS One, v.7, p.1-13, 2012.
OLSON T.A.; LUCENA C.; CHASE JR. C.C.; HAMMOND A.C. Evidence of a major gene influencing hair length and heat tolerante in Bos taurus cattle. J. Anim. Sci., v.81, p.80-90, 2003.

OSEI-AMPONSAH R.; CHAUHAN S.S.; LEURY B.J. et al. Genetic selection for thermotolerance in ruminants. Animals, v.9, p.948, 2019.

PORTO-NETO, L.R.; BICKHART, D.M.; HERNANDEZ, A.J.L. et al. Convergent evolution of slick coat in cattle through truncation mutations in the prolactin receptor. Front. Genet., v.9, p.1-8, 2018.

TURNER, H.G.; SCHLEGER, A.V. The significance of coat type in cattle. Aust. J. Agricul. Res., v.11, p.645-663, 1960

UPADHYAY A.; CHAKRAVARTY A.K.; DE, $S$. et al. Detection of Single-Nucleotide Polymorphism in AGPAT6 Gene, associated with Milk Fat content, using Tetra-Primer ARMS PCR-Based Assay, in Karan Fries Breeding Bulls. Iran. J. Biotech., v.17, p.e2084, 2019. 